\title{
Genetic variants of reduced clopidogrel absorption and platelet reactivity after standard clopidogrel therapy and serial dose tailoring in the NCT02096419 trial: a pharmacogenetic substudy
}

\section{Jure Samardžić*, Nada Božina, Boško Skorić, Marijan Pašalić, Lana Ganoci, Miroslav Krpan, Mate Petričević, Davor Miličić}

Univesity of Zagreb School of Medicine, University HosCroatia pital Centre Zagreb, Zagreb,

\begin{abstract}
CITATION: Cardiol Croat. 2015;10(9-10):205. | DOI: http://dx.doi.org/10.15836/ccar.2015.205
*ADDRESS FOR CORRESPONDENCE: Jure Samardžić, Klinički bolnički centar Zagreb, Kišpatićeva 12, HR-10000 Zagreb, Croatia, / Phone: +385-1-2367466 / E-mail: jure.samardzic@gmail.com

ORCID: Jure Samardžić, http://orcid.org/0000-0002-9346-6402 • Nada Božina, http://orcid.org/0000-0001-6016-1699 Boško Skorić, http://orcid.org/0000-0001-5979-2346• Marijan Pašalić, http://orcid.org/0000-0002-3197-2190 Lana Ganoci, http://orcid.org/0000-0003-3898-4554 • Miroslav Krpan, http://orcid.org/0000-0002-0639-953X Mate Petričević, http://orcid.org/0000-0002-2083-7751 • Davor Miličić, http://orcid.org/0000-0001-9101-1570
\end{abstract}

IIIIIIIIIIIIIIIIIIIIIIIIIIIIIIIIIIIIIIIIIIIIIIIIIIIIIIIIIIIIIIIIIIIIIIIIIIIIIIIIIIIIIIIIIIIIIIIIIIIIIIIIIIIIIIIIIII

INTRODUCTION: Multidrug resistance gene 1 (MDR1) encodes clopidogrel's intestinal efflux transporter P-glycoprotein. Polymorphism in MDR1 exon C3435C $>$ T has been linked to alterations of clopidogrel absorption and the level of platelet inhibiton. ${ }^{1-3}$

PATIENTS AND METHODS: We performed pharmacogenetic analysis from our previously published trial which evaluated the effect of serial clopidogrel dose adjustment based on continuous platelet function testing in acute coronary syndrome patients with initially determined high on-treatment platelet re-

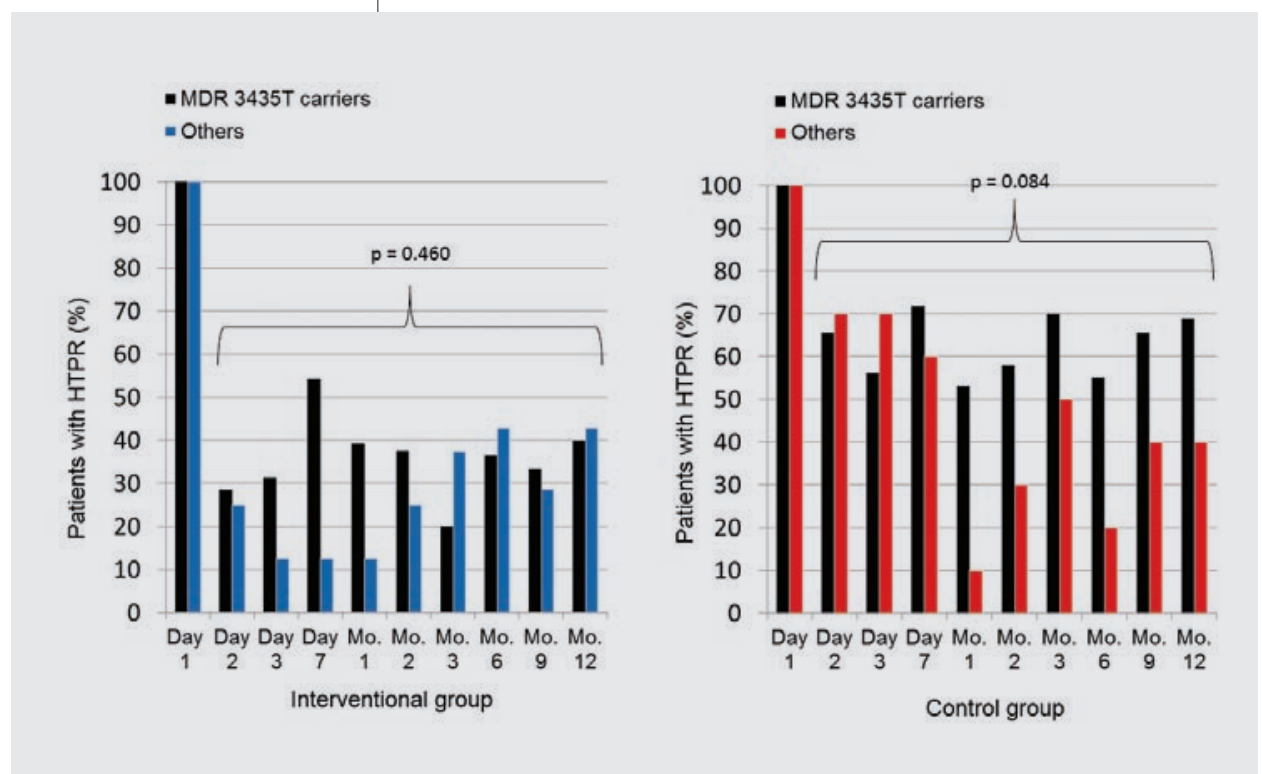

FIGURE 1. The effect of MDR1 $3435 T$ allele on platelet reactivity. activity on clopidogrel. Fourty-two and fourty-three patients were genotyped for MDR1 C3435T from the control group and the interventional group, respectively. PR levels during 12 month follow up were compared between carriers and non-carriers of loss of function allele 3435T.

RESULTS: $3435 \mathrm{~T}$ carriers and noncarriers had similar PR levels in the interventional group $(\mathrm{p}=0.460)$. PR of $3435 \mathrm{~T}$ carriers was higher compared to noncarriers in the control group, however, not statistically significant $(p=0.084)$ during entire follow up period (Figure 1).

CONCLUSION: Presence of MDR1 3435T allele was not associated with statistically significant changes in PR in both groups of patients. Larger trials with adequate power are warranted to confirm these results.

RECEIVED:

August 27, 2015

ACCEPTED:

September 17, 2015

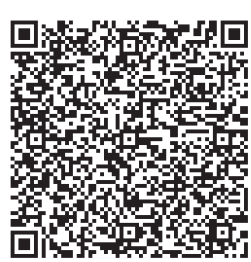

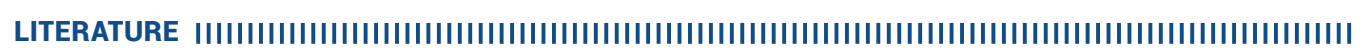
Taubert D, von Beckerath N, Grimberg G, Lazar A, Jung N, Goeser T et al. Impact of P-glycoprotein on clopidogrel absorption. Clin Pharmacol Ther. 2006;80:486-501. DOI: http://dx.doi.org/10.1016/j.clpt.2006.07.007

2. Mega JL, Close SL, Wiviott SD, Shen L, Walker JR, Simon Tet al. Genetic variants in ABCB1 and CYP2C19 and cardiovascular outcomes after treatment with clopidogrel and prasugrel in the TRITON-TIMI 38 trial: a pharmacogenetic analysis. Lancet. 2010;376:1312-9. DOI: http://dx.doi.org/10.1016/S0140-6736(10)61273-1

3. Samardzic J, Krpan M, Skoric B, Pasalic M, Petricevic M, Milicic D. Serial clopidogrel dose adjustment after platelet function testing improves outcome of acute coronary syndrome patients undergoing percutaneous coronary intervention with high on-treatment platelet reactivity. $J$ Thromb Thrombolysis. 2014;38:459-69. DOI: http://dx.doi.org/10.1007/s11239-014-1087-0 